\title{
Søren Kolstrup, Gunhild Agger, Per Jauert \& Kim Schrøder (Eds.): Medie- og kommunikationsleksikon. Frederiksberg: Samfundslitteratur. 2009
}

\author{
Ole Emil Rasmussen
}

MedieKultur 2010, 48, 163-166

Published by SMID | Society of Media researchers In Denmark | www.smid.dk The online version of this text can be found open access at www.mediekultur.dk

Medie- og kommunikationsleksikon indeholder 465 artikler om centrale begreber, teorier, metoder, fænomener og forskere inden for medieteori, mediehistorie, organisationskommunikation, kommunikationsteori, fortælleteori, journalistik, diskursteori, digitale medier, mediesociologi, receptionsanalyse, visuel teori, lingvistik, radio, tv og film.

Leksikonet er det første af sin art i Skandinavien. Leksikonet er skrevet og redigeret af 150 fremtrædende faglige specialister fra Danmark, Norge, Sverige, Finland, Holland, England, Frankrig og USA.

Således lyder forlagets præsentation, og alene den fremkalder store forventninger. Jeg kan tilføje, at læseren får 553 dobbeltspaltede sider og artikler med krydshenvisninger og henvisninger til supplerende læsning. Hertil kommer 11 siders stikordsregister efterfulgt af en litteraturliste på 62 sider og endelig fem siders forfatterliste.

De primære læsere er nok studerende på de videregående uddannelser. De kandidatstuderende må sammen med BA-studerende være en primær målgruppe. Listen ovenfor lover meget, mere end denne anmeldelse kan gabe over. Og leksikonet kan også kun vise sin brugbarhed over tid. Så jeg laver tre stikprøver, en for kandidatstuderende (kommunikation), en for BA-studerende (kommunikation) og så en for gymnasiefaget dansk (medier).

Mine specialeskriveres ene emne er specifikke sam- og modspilsmønstre i personlig kommunikation på italiensk og dansk med fokus på nonverbal kommunikation. De studerendes problemfelt omfatter interkulturel kommunikation. De kan dog ikke finde opslag eller stikord om nonverbal kommunikation og interkulturel kommunikation i leksikonet. De kan 
finde en artikel om Interkulturel medieoplevelse, som ikke er relevant. I stikordsregistret er stikord, der henviser til artikler, ikke særskilt markeret. Så prøver de stikordet Interkulturel transfer, finder de kun en linje i artiklen Interkulturel medieoplevelse. Den artikel findes dog ikke i stikordsregistret. Her kaldes den Interkulturelle udvekslinger. En mulig indgang kunne også være artiklen Kulturel identitet, i sig selv en artikel, der glimrende udreder begreb og problem. Men artiklen vinkles mediemæssigt, ikke kommunikativt. En anden mulig indgang kunne være artiklen Erving Goffman, men det er en kortfattet værkgennemgang, der igen afsluttes med et mediemæssigt perspektiv. Mine studerende må i stedet læse artiklen om Interkulturel kommunikation i den ligeledes nye Kommunikationsteori - en grundbog (Helder, J. m.fl. (Eds.), 2009), hvor redaktionen har afsat 30 sider. I Medie- og kommunikationsleksikon skal de i stedet starte med artiklen Interpersonel kommunikation, som ganske vist ikke står i stikordsregisteret! Her får de så forskningsbaserede henvisninger til nonverbal kommunikation (Wagner, Scherer og Kendon), høflighedsteori (Brown \& Levinson og Goffman) og en præsentation af Konversationsanalyse, der også har sin egen artikel og hele fire henvisninger i stikordsregistret, som nævnt uden markering af hvilket sidetal der henviser til selve artiklen.

Jeg tager en ny stikprøve. To andre specialestuderende skriver om Politisk kommunikation. De kan let finde en artikel (af Finn Frandsen, Handelshøjskolen i Århus. Alle artikler er navngivne. "For overskuelighedens skyld", som redaktionen bemærker i forordet). Artiklen afgrænser begrebet ved at pege på sammenhængen mellem offentlighed, genrer og medieformer med en henvisning til artiklen Retorik. State of the art-indslaget er en teori om det politiske kommunikationssystem (Blumler \& Gurevitch, 1995) med fokus på aktørernes modtagerroller (borgere, journalister og politikere) med henvisning til artiklen Uses and gratifications og i et historisk perspektiv med henvisning til artiklen Offentlighed. De supplerende indslag omfatter politisk marketing med henvisning til Markedskommunikation og spindoktorer (her dog uden henvisning til artiklen Spin).

Mine specialestuderende har som foreløbigt udgangspunkt et problemfelt: "Vi kunne godt tænke os at undersøge, hvordan vi som mennesker former vores politiske holdninger i det komplekse samfund, vi er en del af - foregår dette ud fra et rationelt og objektivt grundlag, eller er det en umulighed? OG hvad er mediernes rolle i alt dette?" Her vil artiklen være en mulig relevant indgang specielt med fokus på det politiske kommunikationssystem.

Jeg laver endnu en stikprøve: BA-projekter i kommunikation. En af mine studerende overvejer i opstartsfasen lige nu tre ideer: "Kommunikationsrådgiverens rolle (magt/funktion) indenfor det politiske system", "Krisekommunikation ifm. den finansielle krise" og "Forandringskommunikation i Spanien ifm. det nye EU formandskab". Som udgangspunkt kan jeg henvise hende til artiklerne Politisk kommunikation, Krisekommunikation og Forandringskommunikation. Den studerende kender vidensområderne i forvejen. Forandringskommunikation præsenteres med cen-lok-perspektivet med udgangspunkt i Helle Petersen (2000). Krisekommunikation præsenterer to forskningstraditioner: en tekstorienteret (Benoit, 1995) og en kontekstorienteret tradition (Coombs, 1999). Rådgiveren i den politiske kom- 
munikation præsenteres i artiklen herom med omtale af Alastair Campbell som leder af Blairs og New Labours kommunikation og strategi 1997-2003, men uden reference til hans bog The Blair Years (2007). Philip Gould burde i denne sammenhæng måske med større ret nævnes med hans The Unfinished Revolution (1998), som var inspirationskilde for Anders Fogh Rasmussen og forvandlingen af Venstre. I denne sammenhæng burde tillige nævnes James Carville, der også var konsulent for Blair, men har indskrevet sig i politisk kommunikations historie som strategisk leder af Clintons præsidentkampagne i 1992, der er fastholdt i den to gange prisbelønnede og Oscar-nominerede dokumentar The War Room (1993).

En sidste stikprøve gælder gymnasiemodtagerne. Her vil leksikonet nok først og fremmest være lærerens bog. Jeg fokuserer her på danskfaget, som efter 2005-reformen er blevet opgraderet på medieområdet. Populære emner i projektopgaver (såkaldte større skriftlige opgaver eller studieretningsopgaver) er film. Der er ni opslag under film. Her er især Filmgenrer, Filmsprog, Filmstil og Filmtyper gode indgange til de typiske projektopgaver, men også Berettermodellen (en gymnasial klassiker) og Karakter og karakterisering (der kan give ilt til en sejlivet folkeskolestereotypi hvor man remser personlighedstræk op) og så Plot (som mange elever har svært ved at forstå og anvende).

Digitalisering, som eleverne nu har oplevet hele deres liv, naturligt som vandet for fisken, men som de næppe i undervisning eller hverdag skænker mange tanker, har 13 gode opslag, hvoraf halvdelen er skrevet af Niels Ole Finnemann. Måske kunne man have samlet parcellerne til en større sammenhængende mark. Binæere alfabet, Web 2.0, Computer og Internet af samme forfatter findes også særskilt, men to af dem står ikke i stikordsregistret.

Bogmediet, som leksikonet selv inkarnerer i en elektronisk medieverden, glimrer ved sit fravær. Heller ikke digitaliseringen af det er nævnt med e-book. Under opslaget Mediematrice kan man dog finde bogtryk-kultur. Wiki har et kort opslag, der dydigt undgår at nævne Wikipedia, som for tiden er gymnasieelevernes foretrukne leksikon sammen med søgemaskinen Google, der heller ikke findes som opslags- eller stikord.

Og her er vi ved spørgsmålet om værkets unique selling point. Et leksikon med forholdsvis korte opslag og mange interne (og indviklede) henvisninger i papirform versus Wikipedia og for den sags skyld Den Store Danske med søgefunktion i elektronisk form. Og hertil kommer konkurrenter i papirform: grundbøger eller håndbøger specialiseret i forskningsfelter. I denne forbindelse kunne nævnes den nu delvis forældede 20 år gamle Mediehåndbogen (Frands Mortensen, Jørgen Poulsen \& Jørgen Stigel (Eds.), 1990), en gymnasial håndbog med forbilledlig emne- og stikordsformidling. Flere af forfatterne er i øvrigt still going strong i det nye Medie- og kommunikationsleksikon.

Stikprøverne viser, at Medie- og kommunikationsleksikon har brugsværdi på niveauerne fra gymnasie- til kandidatuddannelse. De har også vist, at der er nogle sorte huller, men især har de vist, at værket mangler en ordentlig synkronisering af det begrebsnetværk, som et leksikon af denne art er. Manglerne bør udbedres ved et forhåbentlig kommende nyt oplag, herunder også indføring af sidehoved med løbende alfabetbogstav. Stikordsregistret, som man forventeligt bruger meget, burde være anbragt sidst. Nu skal man bladre mellem side 
Book Review: Medie- og kommunikationsleksikon

565 og 575 og ryger hele tiden over i de efterfølgende kapitler med litteratur- og forfatterliste. Og redaktionen bør tage stilling til spørgsmålet om domænetab. Jeg har fx noteret, at man bruger "face-teorien", "facework", "positive og negative faces" (artiklen Interpersonel kommunikation), men "ansigtsarbejdet", "ansigtstab" (i artiklen Erving Goffman). Ingen af begreberne er anført i stikordsregistret. Her står derimod "Facebook"!

Ole Emil Rasmussen
Lektor
Frederiksberg Hf-kursus e
Institut for Internationale Kultur-og Kommunikationsstudier
Copenhagen Business School, Danmark
cultext@mac.com

